\title{
CONSOLIDATED DEMOCRACIES AND THE PAST: TRANSITIONAL JUSTICE IN SPAIN AND
CANADA
}

by lan Dunbar*

* Department of Political Science, Queen's University Belfast, Ireland

Email: idunbar01@qub.ac.uk

\begin{abstract}
The majority of scholarly consideration on the principles of transitional justice has focused upon how emerging democracies should deal with former regimes immediately following violent conflict. However, consolidated democracies have also begun to turn to transitional justice mechanisms in order to address historical legacies of violence and repression. This article examines Spain and Canada, two countries dealing with seemingly disparate issues: the legacy of the Civil War and Franco's repressive regime, and the abuses of the Indian Residential Schools system, respectively. However, both nations have been forced to respond to similar questions regarding the merits of revisiting a painful past well after democratic consolidation. The article first discusses the proliferation of transitional justice principles into consolidated democracies, and considers the argument that such processes may destabilize and divide society, particularly by exacerbating federalist divisions. It concludes that despite the unique challenges of employing transitional justice so long after a transition, the Spanish and Canadian cases reveal the inevitability of confronting the past in response to charges of hypocrisy and illegitimacy. Consolidated democracies, embedded with principles of public contention and debate, are well-suited to respond to these challenges while maintaining political and societal cohesion.
\end{abstract}

Keywords: Spain, Canada, historical legacies and transitional justice mechanisms

Dunbar 2011, "Consolidated Democracies and the Past: Transitional Justice in Spain and Canada", Federal Governance, vol. 8 no. 2, pp 15-28. 


\section{About Federal Governance}

Federal Governance is an online graduate journal on theory and politics of federalism and multilevel governance. Its mandate is to engage the global federalism community and reach out to outstanding graduate students interested in federalism and multi-level governance. By providing a platform for graduate students to have early success in their careers, Federal Governance seeks to promote and sustain interest in federalism and multi-level governance research among graduate students. Allied with the Forum of Federations and founding partner, Institute of Intergovernmental Relations at Queen's University; Federal Governance aims to contribute to a global dialogue on federalism.

Co Chairs, Advisory Committee:

Publisher:

Managing Editor:

Associate Editors:

\author{
Rupak Chattopadhyay and Christian Leuprecht \\ Forum of Federations \\ (Rupak Chattopadhyay and Rod Macdonell) \\ Annegret Eppler \\ Joshua Cerovski, Dominic Heinz, \\ Eva-Maria Maggi and Victoria Tait
}

\section{Terms of Use}

Your use of this Federal Governance article indicates your acceptance of Federal Governance's Terms and Conditions of Use, available at www.federalgovernance.ca/terms. Federal Governance's Terms and Conditions of Use provides that you may use Federal Governance content only for personal, academic and non-commercial use. Each copy of any part of this Federal Governance article must contain the same copyright notice that appears on the screen or printed page of such transmission. 


\section{Introduction}

Recent decades have witnessed an explosion of interest in the principles of transitional justice. The majority of scholarly consideration in this area has focused upon how emerging democracies should deal with former regimes in the immediate aftermath of violent conflict. However, some advanced democratic states have also begun to turn to transitional justice mechanisms in order to address historical legacies of violence and repression. Two such cases are considered here: Spain and Canada. The two countries are dealing with very different histories - in Spain, many citizens are questioning the legacy of the Civil War and Francisco Franco's repressive regime, while Canada is re-examining abuses perpetrated against its aboriginal citizens through the Indian residential schools system. However, both nations have been forced to consider the merits of revisiting a painful past well after democratic consolidation. The article begins by examining the reasons for the sudden proliferation of transitional justice principles into consolidated democracies. Using the cases of Spain and Canada, it then discusses the potential implications of this attitudinal shift, including the argument that re-examining the past may undermine fundamental societal pacts and prove divisive, or even destabilizing. Such concerns are especially pertinent for federal states, where debates over identity and the devolution of powers are often prominent. The article concludes that despite these challenges, advanced democracies are unlikely to avoid confronting the past, evidenced by the prevalence of civil society campaigns for truth recovery in both Spain and Canada. However, the inherent principles of political contention and debate embedded within consolidated democracies make them particularly well-suited to withstand these potentially divisive processes.

\section{The Proliferation of Transitional Justice}

Transitional justice processes in fledgling democracies have been well documented (see for example Kritz 1995; Minow 2000; Teitel 2000). Truth commissions, war crimes tribunals and amnesties have become central features of the political landscapes in Africa, Latin America and post-communist Eastern Europe, and no discussion of postconflict reconciliation is complete without addressing questions of punishment (or lack thereof) for perpetrators of atrocities and human rights abuses. The transitional justice processes in Spain and Canada are significant, however, because they have not occurred in such unstable environments, but rather in 'consolidated democracies.' While this term has been hotly contested and remains somewhat ambiguous, for the purposes of this article, Linz and Stepan's broad definition of a consolidated democracy as "a political regime in which democracy as a complex system of institutions, rules, and patterned incentives and disincentives has become, in a phrase, 'the only game in 
town'" (Linz and Stepan 1996, 15) will suffice. Such commitment to democratic governance is clearly entrenched in both Spain and Canada. By the beginning of the $21^{\text {st }}$ century, when Leòn province witnessed the first controversial public exhumations of Civil War graves, the 'Spanish model' was considered a paradigmatic case of successful transition from authoritarian rule to democracy (Aguilar 2001, 93-99). Similarly, while the 1990s witnessed fierce national unity debates in Canada in the form of the failed Meech Lake and Charlottetown Accords, as well as the near-secession of Quebec in 1995, such disputes were invariably confined to processes of democratic bargaining and deliberation. Unlike more conventional settings for post-conflict transitional justice, the spectre of an immediate return to violence and repressive rule has not been a concern for Spain and Canada; the priority is instead the survival of their federal systems. ${ }^{1}$

The recent proliferation of transitional justice mechanisms into consolidated democracies is indicative of a broader interest in the notion that advanced societies must comprehensively address the sins of the past in order to progress socially and politically. This notion has extended from sweeping public gestures made by governments and religious organizations, to more individualized acts of contrition witnessed in truth commissions and public inquiries. The South African Truth and Reconciliation Commission represents perhaps the most-documented and prominent example of these ideals, but it has been far from an isolated phenomenon. Indeed, the post-Cold War period has been described as an 'age of apology,' prompted by developments in international law and new social movements that have fundamentally questioned popular perception of injustices committed by past regimes, and how governments should adequately respond (Howard-Hassman and Gibney 2008). Barkan and Karn note a remarkable willingness on the part of historical adversaries to engage in what they call "negotiated history" (Barkan and Karn 2006, 8). They cite official apologies from such disparate sources as governments in the former Yugoslavia, Northern Ireland, Japan, the United States, and officials in the Catholic Church to emphasize an increasing willingness on the part of democratic regimes to extend liberal conceptions of individual rights to the group level. In their view, the past is revisited "in the hope of releasing ourselves from the grip of history. We go back in order to go forward with resolve and purpose" (ibid., 26). For many observers of consolidated democratic societies, this willingness to re-examine the past has become an imperative, a measure that is necessary to ensure the legitimacy of the state. Golob asserts that since the Cold War, a "cosmopolitan consensus" of legal and political values has developed, one that legitimizes states based on their adherence to

1 While the 1978 Spanish Constitution does not explicitly reference federalism, Spain is typically classified as at least 'quasi-federal' or a 'hybrid system.' See Encarnación 2004. 
international norms of justice and individual rights (Golob 2002, 25). Governments risk charges of hypocrisy if they extol virtues of universal human rights and the rule of law for democratizing societies without addressing such concerns in their own nations as well.

These criticisms find resonance both domestically and upon the international stage. In Spain, the most prominent example of such sentiments stemmed from the 1998 arrest of former Chilean dictator Augusto Pinochet, spearheaded by Spanish magistrate Baltasar Garzón. For over two decades, Spanish politics had been characterized by a marked unwillingness to address the legacy of Franco's fascist regime after his death in 1975. Under the terms of the broad 1977 Amnesty Law, the mass killings, military show trials and 'disappearances' credited to Franco's regime during and after the Spanish Civil War were not judicially investigated. Given such precedent, the Pinochet indictment prompted intense debate over the moral legitimacy of the Spanish judicial system pursuing another nation's former dictator while ignoring its own repressive history (Encarnación 2007). Civil society organizations, media and politicians alike were galvanized in an attempt to bring Spain up to the same standards of justice and historical memory that it was now promoting to the rest of the world. The most wellpublicized such campaign was spearheaded by the Asociación para la Recuperación de la Memoria Histórica (ARMH, Association for the Recovery of Historical Memory), an organization dedicated to recovering the truth about 'disappeared' persons from the Franco era. Facing governmental indifference, in 2002 the ARMH successfully lobbied the United Nations (UN) Working Group on Forced or Involuntary Disappearances to include Spain on a list of nations facing unresolved cases of state crime and repression. The international reprimand embarrassed the government into abiding by the non-binding recommendation and served to further intensify debates over revisiting Spain's painful past (Davis 2005, 872-874).

Canada has also faced charges of hypocrisy on the international stage over treatment of its aboriginal citizens, most notably with regards to the legacy of its residential schools program. From the late $19^{\text {th }}$ century until the final school closed in 1996, an estimated 150,000 aboriginal children were forcibly removed from their families and placed in the strict church-run institutions, where they were forbidden to speak their languages or practice their cultures (Miller 1996). In 1990, prominent aboriginal politician Phil Fontaine appeared on a national news television program and voiced allegations of widespread physical, sexual and emotional abuse throughout the residential schools system. The admission prompted many other former victims to come forward, raising troubling questions for a nation that prides itself on multiculturalism and tolerance. In 1991 the federal government established the Royal Commission on Aboriginal Peoples (RCAP) to investigate the relationship among Canadian aboriginal communities, the government, and society as a whole. Upon publishing its report in 1996, the RCAP concluded that Canada's international 
reputation for respecting human rights, liberal democracy and diversity had been "tarnished" and represented "at best, a half-truth" (RCAP 1996a). Similar criticisms followed. In 2001 Matthew Coon Come, then National Chief of the Assembly of First Nations (AFN), responded to an unfavourable country report issued by Amnesty International by asserting that "Canada, supposedly the human-rights boy scout of the world, now has its name inscribed in a book of shame" (quoted in Mofina 2001, A10). AFN Grand Chief Edward John echoed similar sentiments in 2007, after the Canadian government declined to sign the UN Universal Declaration of Indigenous Peoples' Rights: "[Canada] cannot present itself as a promoter of human rights internationally when in its own backyard it votes against the human rights issues of indigenous people" (quoted in Edwards 2007, A8).

Certainly, while the challenges facing these two governments echo many similar themes, the cases are marked by considerable differences that make it difficult to draw direct correlations. The Spanish case is striking in its scope, a country-wide transition of government from widespread fascist repression to contemporary democratic governance within a relatively short period of time. Demands for justice measures have focused on a need for remembrance and acknowledgement, symbolized powerfully by exhumation campaigns from relatives of the 'disappeared.' Despite the cross-cutting nature of this transition, or perhaps because of it, the Spanish government has proven reluctant to offer an official position on the conflicts of the past, largely responding instead to individual initiatives and judicial challenges as they have arisen. On the other hand, the scope of Canadian transitional justice, it can be argued, is much narrower than in Spain. Abuses were perpetrated against a specific segment of the population, sharply delineated between aboriginal victims and their nonaboriginal abusers. Along with a desire to generate a historical record of residential schools, there has also been a strong need expressed from many sectors for the achievement of true reconciliation in Canadian society. Recognizing that the existing piecemeal approach of individual lawsuits and church apologies was insufficient for these purposes, in 2006 the Canadian government approved a Truth and Reconciliation Commission (TRC) in 2006 as part of a larger, more comprehensive judicially-approved settlement. However, despite its official sanctioning, the mandate of the TRC is limited to an examination of the residential schools system, not the overall historical treatment of aboriginal citizens in Canada, with a focus on story-telling and raising awareness rather than any retributive or compulsory legal processes.

Despite these differences in scope, needs and approaches to transitional justice in Spain and Canada, a comparison of the two cases provides insight into the burgeoning interest in revisiting the past shown by consolidated democracies. Shifting international norms, increasing civil society pressure and highly-publicized individual cases have proven to be a powerful impetus for change in recent years. The confluence of these factors has led Aguilar to dub contemporary efforts in Spain as "post-transitional 
justice" (Aguilar 2008, 429), a label that seems similarly appropriate in Canada given its long history of peaceful governance. Spain and Canada thus face unique challenges in using the instruments of transitional justice to respond to outstanding questions of abuse, hypocrisy and moral legitimacy.

\section{Undermining the Pacts of Democracy?}

For societies recently emerging from conflict, many theorists view the transitional justice process as one of pacts and agreements over how best to deal with injustices perpetrated by past regimes. Snyder and Vinjamuri, for example, hinge the establishment of a stable political order upon "a political bargain among contending groups and on the creation of robust administrative institutions that can predictably enforce the law" (Snyder and Vinjamuri 2004, 6). While in practice states usually employ varied and nuanced legal approaches, rhetorical debates over the past are more often framed in terms of stark, black-and-white alternatives: truth or justice? Punishment or reconciliation? Prosecution or amnesty? Teitel outlines the choice facing post-conflict societies as such: "Either political change is thought necessarily to precede the establishment of the rule of law or, conversely, certain legal steps are deemed necessarily to precede political transition" (Teitel 2000,3). In consolidated democracies, however, these choices have already been addressed and, at least to a certain extent, settled. Indeed, the existence of widespread agreement on the form and substance of the rule of law is an integral part of Linz and Stepan's definition of a consolidated democracy (Linz and Stepan 1996, 18-19). Revisiting the past through mechanisms such as truth commissions inherently challenges these agreements, raising questions of potential division and instability caused by 'changing the rules of the game' for society. Addressing charges of hypocrisy remains a priority for many citizens, but as Kovras and Loizides point out, for others, "any demand for a comprehensive truth recovery is not a very welcome development because it usually sheds light into the 'notorious' aspects of the activity of previously admired groups and subsequently delegitimizes the predominant discourse" (Kovras and Loizides n.d.).

This issue of division is especially pertinent in countries with federal systems, which historically have endured frequent constitutional crises that threaten the efficacy of the system to regulate conflict (O'Leary 2002). In multinational federations such as Spain and Canada, a bargain of power-sharing exists between competing linguistic or ethnic groups as a means of managing competing claims to nationhood. This arrangement opens up, rather than forecloses, the issue of a state's legitimacy over its constituent groups, normalizing divisive politics and providing a forum for other claims to power and sovereignty (Kymlicka 2009, 11). Many fear that implementing transitional justice measures into such an environment may lend overt credence to the claims of one group over another, precluding the possibility of building or maintaining a shared 
identity. In addition, there are no guarantees that pitting one national narrative against another will not degenerate into unrest and political violence if the outcome of any process is deemed unsatisfactory. However, as Kymlicka asserts, it is likely inevitable that political processes in federal states will be filtered through the lens of these competing national narratives, and as such transitional justice mechanisms may simply provide an alternative outlet for such debates (ibid., 13).

The Spanish case has in recent years demonstrated the passions that can be aroused by demands to reopen judicial and political agreements in order to address the past. The mood of political conciliation that generated the 1977 Amnesty Law was indicative of a broader desire from Spanish society to forget the enmity of the civil war. The Pacto del Olvido (Pact of Oblivion), as this agreement came to be known, reflected widespread fear that the transition of power could degenerate into violence and a return to civil war, as had been the case in 1936. This translated to an intense desire for consensus and reconciliation, with political elites seeking to institutionalize the stability of government (Aguilar 2001, 98). The result was the 1978 Constitution, an "an exquisitely ambiguous compromise" of federalism that sought to appease Basque and Catalan demands for regional autonomy as well as the nationalism of Franco loyalists (Encarnación 2004, 65). The notion of amnesty, drawing political support from both the left and right, was crucial to the stability of the new federal arrangement, legally formalizing the process of forgetting and precluding the possibility of prosecutions for Franco-era crimes. The public overwhelmingly supported the move, reflecting that as with political elites, "fear provided the glue that cemented the willingness of the Spanish public to leave the past behind" (Encarnación 2008, 443). Continued political violence, including over 800 deaths from political murders and terrorist attacks between 1975 and 1980 and a failed military coup in 1981, helped ensure that support for the pact would remain high for decades. Indeed, as Aguilar notes, despite some concerns regarding the judicial legitimacy of the amnesty law, most scholars agree that the Pacto del Olvido was a necessary measure to ensure the success of Spain's transition to democracy (Aguilar 2001, 115-116).

Efforts to revisit this seminal agreement have been met with trepidation by some Spanish citizens and staunch opposition from others. While the goals of truth recovery espoused by the ARMH fell firmly within the 'liberalized consensus' on transitional justice principles, the campaign nevertheless represented a clear criticism of the government's policy of inaction and the terms of the amnesty in general (Davis 2005, 872). A "politics of exhumations" (Kovras 2008) emerged, with the ruling Partido Popular (PP, People's Party) reluctant to provide financial support to the ARMH or allow it to expand the scope of its campaign. Pressure from civil society organizations continued to mount, and in 2002 the PP assented to approve a unanimous parliamentary condemnation of Franco's 1936 coup as an antidemocratic act. The 2004 election of the Partido Socialista Obrero Español (PSOE, Spanish Socialist 
Workers' Party) furthered the shift in political attitudes, with Prime Minister José Luis Rodríguez Zapatero prioritizing the recovery of historical memory (Encarnación 2008, 452). In 2007 the Spanish parliament passed the Ley de Memoria Histórica (Historical Memory Law), approving public recognition of victims from both sides of the Civil War, financial assistance for exhumations, and recognition of the illegitimate nature of Franco's military trials, among other elements. Charges of opportunism and historical revisionism followed, with one PP spokesman accusing the PSOE of attempting to "reopen wounds that have already been able to be cured, wounds that are healed" (quoted in Wood 2006). Another went further, decrying the law as a challenge to Spain's federal underpinnings, representing "nothing more than a further step in the strategy of breaking with the great pact of coexistence amongst Spaniards, which was the transition and the Constitution" (quoted in Davis 2008, 326). The law marked the most comprehensive legislation on the past to date, but the debate is far from settled. In 2008 Garzón once again made headlines by launching a criminal investigation into the fate of thousands of missing persons from the Franco era. The probe was ultimately dropped under pressure from the PP and the Spanish public prosecutor, but relatives of the 'disappeared' have vowed to continue to push the courts to investigate the cases (Keeley 2008).

As in Spain, attempts to address historical injustices in Canada have raised questions regarding the wisdom of revisiting constitutive agreements of the state. While much of the media coverage of the Indian residential schools has focused upon instances of sexual and physical abuse, for many observers they simply represent the most prominent examples of the federal government's policy of assimilation conducted towards its aboriginal population for most of Canada's history. Indeed, in its 1996 report, the RCAP concluded bluntly:

"From the early nineteenth century until about the end of the 1960s, displacement, the downgrading of the relationship, and an overall devaluing of the shared history of Aboriginal and non-Aboriginal peoples in the northern half of the North American continent was accepted in mainstream Canadian society (RCAP 1996b)."

The paternalistic and authoritarian nature of the educational system contributed greatly towards these attitudes. The federal government hoped that by removing children from their families and inculcating them with more 'European' values, they could bring about economic self-sufficiency for aboriginal communities as inexpensively as possible (Miller 1996, 414). The official stance of the government changed with the passage of the 1988 Canadian Multiculturalism Act and the end of the residential schools program, but many feel that assimilationist attitudes remain. Miller asserts that in recent years, politicians at both the federal and provincial levels have continued to employ a "weknow-what's-good-for-you attitude" in relation to aboriginal issues (ibid., 436). In 2006, the AFN issued a 'report card' criticizing the government for its inaction in implementing 
the recommendations of the RCAP. Significantly, the report observed "no structural changes in the relationship between First Nations and the Canadian government" (AFN 2006) a serious charge considering the scale of the historical injustices of the past.

While public support for some forms of redress such as Prime Minister Stephen Harper's official apology in 2008 has been relatively high, some observers are concerned that delving further into a painful period of Canadian history will prove inherently divisive. As Kernerman notes, "While [Canadians] reject aggressive and assimilative national identities, this very rejection cultivates nationalist anxieties, increasing the urge to constitute the Canadian political community" (Kernerman 2006, 8). By such views, mechanisms such as the Indian Residential Schools Truth and Reconciliation Commission (TRC), established in 2006 as part of a larger judiciallyapproved settlement, may simply regress into an accusatory process and prompt resentment from some segments of society. Transitional justice scholar Ronald Rotberg has labelled the commission an unnecessary "flagellation" that, given its limited mandate and belated implementation, is unlikely to achieve any significant reconciliatory function (quoted in MacDonald 2008, 24). Such debates have produced significant problems for fledgling TRC. In October 2008, Justice Harry Laforme resigned his position as chairman, citing the unwillingness of his colleagues to prioritize reconciliation over other concerns such as truth recovery (Friesen 2008, A8).

Transitional justice mechanisms such as the TRC have also been co-opted into broader debates surrounding Canadian federalism and aboriginal self-governance. Critics have asserted that any meaningful redress for residential school survivors must be broadened to sufficiently address these fundamental issues, dismissing existing judicial processes as "state-based" (Corntassel and Holder 2008) or a measure of "social control" (Funk-Unrau and Snyder, 2007). In a federalist nation where questions of 'unity versus diversity' are never far from the political sphere, the notion of devolving power to any particular group is inevitably contentious. The government's rejection of the UN Universal Declaration of Indigenous Peoples' Rights was based on concerns that the document was inconsistent with the constitution and could lead to legal challenges of previously settled land claims (Edwards 2007, A8). A discourse of 'equality over a hierarchy of rights,' voiced by opponents of aboriginal self-governance during debates over the failed Meech Lake Accord, has proven resilient in recent years (Kernerman 2005, 77). Indeed, as James observes, many scholars view the emergence of "redress politics" as a real threat to social cohesion and the stability of the Canadian welfare state (James 2006, 223).

\section{Meeting the Challenge}

Consolidated democracies seeking to address historical injustices are thus faced with a central paradox: can transitional justice be effective so long after transition? It has 
been 70 years since the end of Spain's divisive civil war, and over 30 years since Franco's death marked the end of fascism and left the nation facing an uncertain future. In Canada, nearly two decades have passed since the first major allegations of residential schools abuse stunned the nation, providing an emphatic indictment of government policies of assimilation that stretched back more than a century. What is displayed by both cases, however, is that despite the often uncomfortable consequences of re-examining the past, simply adopting a policy of 'forgive and forget' is unlikely to provide any long-term solution. The sudden emergence of the historical memory movement in Spain reveals that the Pacto del Olvido was indeed a misnomer - for the victims of the civil war and Franco's regime, nothing was consigned to oblivion and forgotten; merely shelved temporarily in the pragmatic interests of peace. While the prevalence of scattered political murders and the 1981 coup attempt demonstrated the fragility of the transitional period, by the time the ARMH campaign first emerged in 2000, recidivism into violence was increasingly unlikely. The passage of time, combined with seminal events such as the Pinochet indictment and public exhumations, helped change the 'political opportunity structure' in Spain and permitted for the first time a broad discussion of the wounds of the past (Blakely 2005; Encarnación 2008; Kovras 2008). Similarly in Canada, J.R. Miller asserts that Fontaine's highly publicized revelation of sexual and physical abuse "opened the floodgates...that someone as prominent as he was talking about some pretty painful experiences made it easier for victims to talk openly" (quoted in MacDonald 2008, 24).

Of course, the mere fact that civil society and government officials are engaging in some form of shared reflection upon the past does not ensure that the needs and desires of all parties involved will be recognized or satisfied. As noted earlier, the transitional justice instruments by the Canadian government have maintained a relatively narrow scope in considering residential schools exclusively. Many aboriginal leaders have insisted that the negative impacts of the schools transcended individual survivors, leaving a legacy of cultural damage and intergenerational abuse and neglect that has permeated all aspects of the relationship between aboriginal and nonaboriginal societies. Existing transitional justice mechanisms, they contend, represent nothing more than a continuation of the Canadian government's historical usurpation of aboriginal sovereignty (Jung 2009). As such, the limited mandate of the TRC and other transitional justice instruments may be insufficient to achieve the level of reconciliation desired. Certainly, expanding the scope of transitional justice measures in Canada to include debates over government authority vis-a-vis aboriginal groups may prove contentious. Canada's asymmetric federalism, according to many, has already created a schism between Quebec and English-speaking Canada to the detriment of national unity. However, as the Spanish case reveals, certain constitutive federal arrangements can be revisited in a manner that does not necessarily mean contradicting them, but 
rather as a means towards recognizing the inequalities created by the system (Aguilar 2008, 430).

The recent controversy sparked in Spain by Garzón's judicial probe and the continuing problems plaguing the fledgling Canadian TRC demonstrate that achieving consensus over issues of transitional justice is unlikely any time soon. Despite these difficulties, it is the very characteristics inherent to consolidated democracies that ensure their ability to withstand critical re-evaluations of their constitutive agreements. The campaigns of civil society organizations like the ARMH or AFN have certainly raised serious challenges for their respective governments, prompting criticism from those who accuse them of fomenting divisions and undermining the unity of the state. However, as Linz and Stepan argue, while this discourse of "civil society versus the state" has proven useful for fledgling democratic movements struggling against repressive regimes, it is problematic when applied to consolidated democracies. Rather, they argue that the ability of civil society to generate contentious debates and raise political alternatives provides a crucial contribution to the strengthening and deepening of democratic ideals in a society (Linz and Stepan 1996, 17-8). Accusations of injustice and demands for reparations may indeed prove controversial, but as James notes, "redress campaigns are promoting precisely what severely fractured societies lack; common civic discussion around contentious aspects of a shared problematic history" (James 2006, 243). In both Spain and Canada, the legacies of fear and shame that silenced victims for decades have been eroded, and determined movements to recover the truth have inexorably emerged. It seems unlikely that providing redress and a forum for victims to discuss their experiences would prove more divisive than simply allowing old wounds to fester for the sake of 'unity.'

Questioning the fundamental pacts and agreements of a state, therefore, need not be seen as a destabilizing process but rather an assessment of how to improve upon them. As Aguilar notes, "Democracies are able to withstand coexisting heterogeneous memories considerably better than dictatorships" (Aguilar 2002, 268). Especially in federal systems, where competing claims for sovereignty and authority often intrude on any important political decisions, transitional justice measures are certain to be marshalled by certain groups as evidence of the legitimacy of their cause. Despite this, Kymlicka contends, attempting to separate past injustices from ongoing sovereignty debates may generate an incomplete result as "it leaves unexplored the deeper cultural and political forces that made these human rights violations possible" (Kymlicka 2009, 13). Indeed, violent events such as the 1990 Oka Crisis in Quebec, which witnessed Mohawk warriors clashing with police officers during a protest over unsettled aboriginal land claims, vividly demonstrate the potential risks of failing to respond to grievances over fundamental issues. 


\section{Conclusions}

For both Spain and Canada, revisiting the past has proven difficult. The retroactive nature of pursuing justice so long after the fact raises real challenges of division and instability, and inevitably entails deep introspection, painful memories and potentially discordant accusations. It is unlikely that any process of transitional justice will satisfy all involved - invariably, some will demand further truth recovery and punitive measures, while others will maintain an interest in keeping history buried and forgotten. However, this article has argued that in consolidated democracies, simply ignoring the injustices of the past is impossible; the fervour of the campaigns launched by Franco's victims and the survivors of the Indian residential schools attests to this. Responding to these calls is necessary to address charges of moral hypocrisy, and the cases of Spain and Canada show that consolidated democracies can withstand the ensuing pressures. Haltingly but surely, their governments have taken steps to critically examine dark periods of their histories and provide redress to the segments of society that have suffered repression and marginalization. Ultimately, success will be measured by their ability to draw lessons for the future from the ghosts of the past. 


\section{References}

[1] Aguilar, Paloma. 2008. Justice, Politics and Memory in the Spanish Transition. In The Politics of Memory and Democratization, eds. Alexandra Barahona de Brito, Paloma Aguilar and Carmen González-Enríquez, 92-118. Oxford: Oxford University Press, 2001.

[2] - 2002. Memory and Amnesia: The Role of the Spanish Civil War in the Transition to Democracy. New York: Berghahn Books.

[3] - 2008. Transitional or Post-transitional Justice? Recent Developments in the Spanish

[4] Case. South European Society and Politics 13 (4): 417-433.

[5] Assembly of First Nations. 2006. Royal Commission on Aboriginal People at 10 Years: A Report Card. http://www.afn.ca/cmslib/general/afn_rcap.pdf (accessed April 10, 2009).

[6] Barkan, Elazar, and Alexander Karn. 2006. Group Apology as an Ethical Imperative. In Taking Wrongs Seriously: Apologies and Reconciliation, eds Elazar Barkan and Alexander Karn, 3-32. Stanford: Stanford University Press.

[7] Blakeley, Georgina. 2005. Digging Up Spain's Past: Consequences of Truth and Reconciliation. Democratization 12 (1): 44-59.

[8] - 2008. Politics as Usual? The Trials and Tribulations of the Law of Historical Memory in Spain. Entelequia. Revista Interdisciplinar: Monográfico 7: 315-330.

[9] Corntassel, Jeff, and Cindy Holder. 2008. Who's Sorry Now? Government Apologies, Truth Commissions and Indigenous Self-Determination in Australia, Canada, Guatemala and Peru. Human Rights Review 9: 465-489.

[10] Davis, Madeleine. 2005. Is Spain Recovering its Memory? Breaking the Pacto del Olvido. Human Rights Quarterly 27: 858-880.

[11] Edwards, Steven. 2007. Ottawa faces setback over UN human rights declaration. The Vancouver Sun September 13, 2007: A8.

[12] Encarnación, Omar. 2004. Democracy and Federalism in Spain. Mediterranean Quarterly 15 (1): 58-74.

[13] - 2007. Pinochet's Revenge: Spain Revisits its Civil War. World Policy Journal, Winter 2007/2008: 39-50.

[14] - 2008. Reconciliation After Democratization: Coping with the Past in Spain. Political Science Quarterly 123 (3): 435-459.

[15] Friesen, Joe. 2008. Resignation paralyzes residential schools panel. The Globe and Mail October 21, 2008: A8.

[16] Funk-Unrau, Neil, and Anna Snyder. 2007. Indian Residential School Survivors and State-Designed ADR: A Strategy for Co-Optation? Conflict Resolution Quarterly 24 (3): $285-304$. 
[17] Golob, Stephanie R. 2002. Forced to Be Free: Globalized Justice, Pacted Democracy and the Pinochet Case. Democratization 9 (2): 25-57.

[18] Howard-Hassman, Rhoda E., and Mark Gibney. 2008. Introduction: Apologies and the West. In The Age of Apology: Facing Up to the Past, eds. Mark Gibney, Rhoda E. Howard-Hassmann, Jean-Marc Coicaud and Niklaus Steiner, 1-12. Philadelphia: University of Pennsylvania Press.

[19] James, Matt. 2006. Do Campaigns for Historical Redress Undermine the Canadian Welfare State? In Multiculturalism and the Welfare State: Recognition and Redistribution in Contemporary Democracies, eds.Keith Banting and Will Kymlicka, 222-246. Oxford: Oxford University Press.

[20] Jung, Cindy. 2009. Research Brief: Transitional Justice for Indigenous People in a Non-transitional Society. International Center for Transitional Justice. http://www.ictj.org/static/Publications/ldentity_Jung_NonTransitionalSocieties.pdf (accessed 23 April 2010).

[21] Keeley, Graham. 2008. Judge Baltasar Garzón quits probe into fate of Franco 'disappeared.' The Times Online, November 19, 2008. http://www.timesonline.co.uk/tol/news/world/europe/article5182162.ece (accessed April 20, 2009).

[22] Kernerman, Gerald. 2005. Multicultural Nationalism: Civilizing Difference, Cultivating Community. Vancouver: University of British Columbia Press.

[23] Kovras, losif, and Neophytos Loizides. 2009. Hegemonic Beliefs and Delay in Truth Recovery for Missing Persons.

[24] Kovras, losif. 2008. Unearthing the Truth: The Politics of Exhumations in Spain and Cyprus. History and Anthropology 19 (4): 371-390.

[25] Kritz, Neil J. ed. 1995. Transitional Justice: How Emerging Democracies Reckon with Former Regimes, Washington: United States Institute of Peace Press.

[26] Kymlikca, Will. 2009. Transitional Justice, Federalism, and the Accommodation of Minority Nationalism. Oxford Centre for the Study of Inequality and Democracy Working Paper OSCID 5.

[27] Linz, Juan J., and Alfred Stepan. 1996. Toward Consolidated Democracies. Journal of Democracy 7 (2): 14-33.

[28] Macdonald, Nancy. 2008. To Forgive or Forget. Macleans 121 (24): 24-25.

[29] Miller, J.R. 1996. Shingwauk's Vision: A History of Native Residential Schools. Toronto: University of Toronto Press.

[30] Minow, Martha. 200. Between Vengeance and Forgiveness: Facing History After Genocide and Mass Violence, Boston: Beacon Press.

[31] Mofina, Rick. 2001. Amnesty both hails, condemns Canada over human rights. The Gazette (Montreal) May 31, 2001: A10.

[32] O'Leary, Brendan. 2002. The Elements of Right-Sizing and Right-Peopling the State. In Right-sizing the State: The Politics of Moving Borders, eds. Brendan O'Leary, lan S. Lustick and Thomas Callaghy, 15-73. Oxford: Oxford University Press. 
[33] Royal Commission on Aboriginal Peoples. 1996a. People to People, Nation to Nation: Highlights from the Report of the Royal Commission on Aboriginal Peoples. Indian and Northern Affairs Canada. http://www.ainc-inac.gc.ca/ap/pubs/rpt/rpt-eng.asp (accessed April 11, 2009).

[34] -. 1996b. Report, Volume 1: Looking Forward Looking Back. Indian and Northern Affairs Canada. http://www.collectionscanada.gc.ca/webarchives/20071115053257/http://www.aincinac.gc.ca/ch/rcap/sg/sgmm_e.html (accessed April 28, 2009).

[35] Teitel Ruti G. 2000. Transitional Justice. Oxford: Oxford University Press.

[36] Snyder, Jack, and Leslie Vinjamuri. 2003. Trials and Errors: Principles and Pragmatism in International Justice. International Security 28 (3): 5-44.

[37] Wood, Danny. 2006. Civil War Legacy Divides Spain. BBC News July 18, 2006. http://news.bbc.co.uk/2/hi/europe/5192228.stm (accessed April 20, 2009). 